\title{
Universiteit
}

Leiden

The Netherlands

\section{The five: the untold lives of the women killed by Jack the Ripper}

Lister, K.; Milne-Smith, A.; Heijden, M.P.C. van der; Colpus, E.

\section{Citation}

Lister, K., Milne-Smith, A., Heijden, M. P. C. van der, \& Colpus, E. (2020). The five: the untold lives of the women killed by Jack the Ripper. Women's History Review, 29(5), 903-909.

doi:10.1080/09612025.2020.1720092

Version: $\quad$ Publisher's Version

License: $\quad$ Licensed under Article 25fa Copyright Act/Law (Amendment Taverne)

Downloaded from: https://hdl.handle.net/1887/3200593

Note: To cite this publication please use the final published version (if applicable). 


\section{The five: the untold lives of the women killed by Jack the Ripper}

\section{Kate Lister, Amy Milne-Smith, Manon Van Der Heijden \& Eve Colpus}

To cite this article: Kate Lister, Amy Milne-Smith, Manon Van Der Heijden \& Eve Colpus (2020) The five: the untold lives of the women killed by Jack the Ripper, Women's History Review, 29:5, 903-909, DOI: 10.1080/09612025.2020.1720092

To link to this article: https://doi.org/10.1080/09612025.2020.1720092

\section{Published online: 03 Feb 2020.}

Submit your article to this journal $\square$

山 Article views: 527

Q View related articles ๘

View Crossmark data $\nearrow$ 
The five: the untold lives of the women killed by Jack the Ripper, by Hallie Rubenhold, 2019, London, Doubleday, x + 416pp., £16.99, ISBN: 9780857524485

The lives of Mary Ann 'Polly' Nichols, Annie Chapman, Elizabeth Stride, Catherine Eddowes, and Mary Jane Kelly may well have passed unnoticed into the faceless history of Victorian London were it not for how they died in the autumn of 1888. Now known as the 'canonical five', Polly, Annie, Liz, Catherine, and Mary Jane are the infamous victims of the serial killer, Jack the Ripper.

In death, these women attained an almost cult-like status in popular history as countless historians, amateur sleuths, authors, and the self-styled Ripperologists have tried to unmask their killer. The very name, Jack the Ripper, evokes hackneyed images of dimly lit streets, a shadowy figure, cloaked in black, the swirling smog, and, of course, prostitutes. The impoverished women who sold their bodies in the slums of Whitechapel are as much a part of the Ripper mythology as the killer himself. The canonical five may be famous, but they have never been 'real' women to us. As Jack the Ripper became legendary, his victims became little more than a sensationalist plot device in the story of their murderer. Despite hundreds of books, documentaries, and websites dedicated to uncovering the identity of Jack the Ripper, the identity of his victims has never extended much beyond the effacing label of 'prostitute'. Hallie Rubenhold's The Five: The Untold Lives of the Women Killed by Jack the Ripper is the first in-depth study of the lives, rather than the deaths, of the canonical five.

The story of the Ripper has always been one of fragments, and the lives of his victims are no different. Rubenhold is an emotive storyteller as much as she is a historian and deftly spins imagination around the available facts to bring the canonical five to life. Rubenhold mines Victorian parish registers, birth, marriage, and death records, rate books, workhouse records, and court documents to flesh out the lives of Polly, Annie, Liz, Catherine, and Mary Jane. Newspapers, debates in parliament, and the accounts of social commenters such as Henry Mayhew and Charles Booth, provide the canvas for Rubenhold to paint in the backdrop of grinding poverty that overshadowed the lives of London's East End.

One of the key revelations of the book is that only two of the five women who were murdered-Elizabeth Stride and Mary Ann Kelly—earned their money by selling sex. This claim fundamentally disturbed the Ripper narrative and has led to Rubenhold being the subject of considerable online abuse from the Ripperologists who are certain these women 'must' have been selling sex because of the poverty they endured.

There is, and always will be, room to debate what the sources tell us about how these women earned their money. For example, one of the last people to see Polly Nichols alive was the deputy keeper at Wilmott's lodging house at roughly 1.20 on the morning of 31st August 1888. When he turned Polly away, she had scoffed, 'I'll soon get my doss money. See what a jolly bonnet I've got now' (p.83). Much has been made of this fragment. What did Polly mean? How did she intend to make her money? Was she going to pawn her jolly bonnet or wear it to attract a customer?

Maybe these women did sell sex, although as Rubenhold demonstrates the evidence for this is far from certain. But what has been laid bare is the determination to make these women 
'prostitutes', both at the time and today, in order to fit a more salacious narrative. The stigma surrounding sex work and sex workers has blinded historians to the social nuances at work. Today, the sex trade is a diverse and complex experience, ranging from full-service sex workers to dancers, sugar-babies, and BDSM providers (bondage, discipline, sadism, masochism). All sell a sexual service, but few would call themselves a 'prostitute'. Conversely, Victorian society would have comfortably labelled anyone selling a sexual service as a prostitute, as well as any woman living with a partner out of wedlock. What is meant by 'prostitute' can vary considerably but however it is deployed it is tangled in assumptions about a woman's morality and worth. As Rubenhold shows, we have assumed much about these women, but have known very little.

This is not a history of a killer. Rubenhold has no interest in who murdered these women. All trace of the killer has been cut out of this story. There are no autopsy reports, no pouring over injures; in fact, there are no descriptions of the murders at all. This is a history of workingclass women and the crushing poverty of Victorian London. Once we move beyond the limiting label of 'prostitute', complex, vibrant, and devastating stories emerge. Penned in by poverty, blighted by addiction, and stigmatized as the undeserving poor, the lives of these women are painfully alike. One cannot help but rail at the crushing weight of circumstance that denied these women, and doubtless thousands of others, any chance of escaping the slums.

It is now all but impossible conclusively to solve the murders of Polly, Annie, Liz, Catherine, and Mary Jane. The surviving evidence is open to interpretation and there are some who read the sources differently to Rubenhold. But even if it were possible to solve this case, even if evidence emerged to prove these women were all selling sex, this book is still a triumph because it has wrestled focus away from the killer and back on to his victims. The vivid biographies that Rubenhold has delivered makes for uncomfortable reading. Not for the harrowing descriptions of poverty and abuse, nor even knowing how these women met their end, but because it has taken 131 years for their stories to be told at all.

Kate Lister Leeds Trinity University

@ k.lister@leedstrinity.ac.uk

\section{The five: the untold lives of the women killed by Jack the Ripper, by Hallie Rubenhold, 2019, London, Doubleday, $x+416 p p ., £ 16.99$, ISBN: 9780857524485}

It is hard to underestimate the popular interest in Jack the Ripper. There are few historical topics that have such widescale public interest that they actually spur their own branch of study: Ripperology. However, historians' voices are often drowned out in the cacophony of armchair detectives, true crime lovers, and gothic horror fans. Because the Whitechapel murders were such a sensation at the time and spurred countless public debates, there is actually an enormous amount of material still left for historians to tackle. The pioneering work done by Judith Walkowitz, Lee Perry Curtis, and Drew Gray amongst others demonstrates how the murders open up possibilities for exploring the complex history of gender, sexuality, urban life, the press, poverty, race, and policing. While the murder victims are not ignored in this historiography, they are pushed to the background. Meanwhile, in some works of Ripperology they become props or caricatures.

Hallie Rubenhold clearly wants these women to be placed at the heart of our understandings of this tragedy. Rubenhold's book is essentially mini biographies of the canonical five women believed to be killed by a single serial killer in the autumn of 1888 in the East End of London. Greatly expanding on the research of genealogists and amateur historians, she 
thoroughly and poignantly reconstructs the lives of the five working-class women, and is able to trace four of them back to their childhoods. She demonstrates how historians might reconstruct details of working-class women's lives through their interactions with the state. In fact, it is precisely because these women fell on desperate times that they have become easier to track through institutional records.

The book became controversial amongst the Ripperology community before it was even published, largely because of Rubenhold's contention that only two of the five women were prostitutes. The idea that a single man killed prostitutes is so engrained in the mythos of Jack the Ripper that this was sure to cause controversy. The vitriolic and misogynistic commentary by some members of that community seemed only to prove Rubenhold's point in her conclusion that the mythology of Jack the Ripper is predicated on dehumanizing the victims of the murders. While a powerful conclusion, this final chapter also introduces key contextual elements about Victorian prostitution that might be unknown to the general reader. To use women's status as prostitutes as a way to dismiss their value is a travesty, and in some ways fuels the horrific industry of Jack the Ripper entertainment that treats the bodies of these women with such disrespect.

It is difficult to assess Rubenhold's work strictly as a work of academic scholarship. This is a book written for a popular audience. While it is grounded in archival research and is written in a clear way, some statements are clearly meant to address general readers. For example, when Rubenhold states that few books relate the story of the 1887 Trafalgar Square riots or Bloody Sunday, she clearly means in general history texts, since these events are well known and documented in academic works. However, unlike some recent crossover works that fail to recognize the work of academics, or the importance of understanding the specific historical context of the time and place, Rubenhold has clearly immersed herself in the moment of late-Victorian London. For those pulled in by the story of Jack the Ripper, they will get a complicated and nuanced picture of working-class women's lives. This book is a clear example of how to use people's inherent interest in the gruesome Whitechapel murders in order to tell a far more interesting story. The book introduces not only details of five women's lives and histories, but through them, the complex lives of working-class Londoners.

Mary Jane Kelly is the most enigmatic figure in the book, as Rubenhold admits it is impossible to trace her life back to childhood. Yet this does not lessen the impact of her story, and in some ways perhaps gives greater urgency to the need to explore the lives of those whose traces in the historical archive were slim. Mary Kelly was a young woman who rewrote her own history to her contemporaries, making an accurate life story impossible, but her self-fashioning and reimagining of herself speaks to the complexity and agency of poor women's experiences.

Whether or not these women were active prostitutes when they died is in some ways beside the point. The Victorian definition of prostitution was incredibly wide and varied. As Rubenhold acknowledges, the definition of casual prostitution is particularly fraught. She also clearly recognizes that the act of prostitution could vary between acts of intercourse, and hurried groping or fondling in dark alleys. And, in fact, many Victorian moralists would have seen any woman who had a sexual relationship outside of marriage as a prostitute, thus explaining why commentators, police and journalists were often quick to identify all of the victims as prostitutes. The women may or may not have been engaged in the sex trade and, given sources available, it is impossible emphatically to declare that these women were not prostitutes. Most of the sources we have about these women are contradictory, mediated, and complicated. Authorities determined they were 'unfortunates' and 'fallen' women and the media replicated this story ad nauseum. While their friends and neighbours might have denied this fact, that could have been because it was untrue, or it could have been because they 
knew full well how quickly such women were dismissed. Whether or not these women ever engaged in sexual acts for payment should not matter in the equation of how we treat them; a lesson anyone studying serial killers should remember going forward. Those who dismiss Rubenhold's book so vehemently miss the point of the story-we will never know who killed these women, but we can absolutely use the opportunity of their deaths to learn more about them, their families, and the lives of those who lived in the slums of Whitechapel.

Amy Milne-Smith

Wilfrid Laurier University

Q amilnesmith@wlu.ca

The five: the untold lives of the women killed by Jack the Ripper, by Hallie Rubenhold, 2019, London, Doubleday, x + 416pp., ISBN: 9780857524485

The case of Jack the Ripper is much more than a nineteenth-century British story about a London killer, his victims and the sensational newspaper reporting that followed. The murder case appealed to the imagination of people on the continent and in the United States as much as it did in Britain. The speculations about the murderer's identity, the motives and the circumstances in which the women were found, gave rise to numerous films, television series, articles and books that found a market of watchers and readers all over the world.

All five victims of Jack the Ripper were women who had their throats cut in the East End district of Whitechapel; four of them were eviscerated. The particularities of the case raised many questions: why did no-one notice these killings in the densely populated streets of London's East End district of Whitechapel? What moved the perpetrator to brutally kill and mutilate five women in such a short period of time (between 31 August and 9 November 1888)? Why did the killer choose these women to be his victims? The killings also marked a new area in violent crime, notably the 'invention' of the serial killer, detailed newspaper reporting on crime, and major involvement of city dwellers in solving crime. More importantly, the killings marked a period of crucial societal change: a period that was characterized by a growing awareness of the desperate conditions in impoverished parts of the city, rising concern about the link between living conditions and immorality, prostitution and crime, and ultimately, emerging notions about the importance of welfare and wellbeing.

The book written by Hallie Rubenhold is in part a story of the destitute world of the women that fell victim to Jack the Ripper, about their poor lives and their positions in nineteenthcentury London. But the book is also a rehabilitation of the five women. As Rubenhold puts it in her introduction: 'the victims of Jack the Ripper and their lives have become entangled in a web of assumptions, rumour and unfounded speculation' (p. 14). The main argument of the book is that these speculations merely reflected the values of a male authoritarian middle class, which remained unchallenged and have not been critically examined so far. Rubenhold intends to unravel the unproven stories of the five women involved and tell their 'true stories'. As a social historian I find the last objective problematic. Considering that scholars generally aim at contributing to academic debates on the basis of clearly outlined methodologies and careful analysis of sources, there are few social historians or crime historians who would claim that their findings represent 'true stories'. The text on the back cover of the book explains the angle of the author; Rubenhold is a social historian whose expertise lies in revealing stories of previously unknown women in history. It would only be fair to assess her study from this point of view. 
The author's most important 'discovery' is that there is no hard evidence to suggest that all of these women were prostitutes, and that in fact probably three of them were not prostitutes at all. Furthermore, the killings were most likely, as often assumed, not sex related. Rather, Rubenhold strongly claims, the perpetrator may have chosen his victims for other reasons. Being unprotected, vulnerable and homeless women who slept on the streets (or in one case in bed) while being attacked, the killer could easily commit his crime without any rumour. Rubenhold has examined a broad range of sources (coroners' inquests; newspaper reports; parish registers; court registers; birth, marriage and death records; and the archives of the London workhouses) and the conclusions seem plausible, but there is no hard evidence to support these claims. The most informative sources, the coroners' inquests, are largely missing (only two of the five cases have been preserved). What remains is what the author herself describes as 'a body of edited, embellished, misheard and reinterpreted newspaper reports' (p. 16). That seems a shaky basis for the strong claim of 'true' stories.

However, by shifting the attention from the perpetrator to the lives of the women, Rubenhold's study offers new and valuable insights that are based on stronger evidence. The strength of the book lies in the careful reading of sources and literature that place the lives of these five women in the context of urban poverty. The five chapters, each focusing on a different victim, reveal the hardship and social circumstances that shaped the lives of the large majority of poor women living in London (or any other densely populated city) at the end of the nineteenth century. Polly, Annie, Elizabeth, Kate and Mary Jane shared remarkably similar life styles, at least at the end of their lives, and they faced comparable hardship. Although some of the women began life in respectable families, experienced strong family relations and support, got married, had children, and found work or had male partners who (temporarily) supported them, they all ended up as women alone. Similarly, alcohol and desperation were common denominators among the five women, who all had lost the support of their families at the end of their lives. Living the lives of women alone, without family support, without a husband to maintain them, without the means sufficiently to support themselves, and in four cases without a home, they belonged to the lowest and most vulnerable social layers of London.

Rubenhold vividly shows the few options available to women in their positions, and emphasizes justly that double standards regarding extra-marital sex, lower wages and less education opportunities, made it even harder for women to survive. Some of them gave birth to children outside wedlock, were arrested for vagrancy or drunken disorderliness or experienced domestic violence. During their lifetimes, Polly, Elizabeth and Kate were forced to enter the workhouse or venereal hospital, places that were visited by the most destitute and miserable persons of urban society. The most added value of this book is therefore not the 'discovery' that the five were not prostitutes, but the context that is offered which shows the vulnerable, unprotected and weak positions of many women alone in big cities in the nineteenth century.

Manon Van Der Heijden Leiden University

@ m.p.c.van.der.heijden@hum.leidenuniv.nl

\section{The five: the untold lives of the women killed by Jack the Ripper, by Hallie} Rubenhold, 2019, London, Doubleday, x + 416pp., £16.99, ISBN: 9780857524485

On the back pages of her book, The Five: The Untold Lives of the Women Killed by Jack the Ripper, Hallie Rubenhold has written an epilogue, entitled, 'A Life in Objects', listing the possessions that were found on the persons of four of the five women killed on the streets of Whitechapel, East London in the summer and autumn of 1888: (Mary Ann) Polly Nichols, 
Annie Chapman, Elizabeth Stride and Catherine Eddowes-Mary Jane Kelly was killed in the room in which she slept off those same streets. Drawn from the inventories compiled by the police at the scene of the women's murders, this is historical evidence of lives lived in extreme destitution. The lists of the women's possessions combined fit onto three and half pages of the book; other than the clothes covering their bodies, the most impoverished of the women, Polly, had just three items; Annie had four.

Rubenhold's central goal in The Five, which is targeted at the general reader as much as the academic one, is to recover the stories of the women whose deaths have been recounted since their murders as the victims of Jack the Ripper. In the process she contests the claim that 'the five' were all prostitutes. Her conclusion goes against a general tendency in which the five women feature as little more than their names and their presumed identity as prostitutes. Although there is a rich stream of academic scholarship exploring the constructed narratives of the murders, Rubenhold marshals a distinctively feminist argument. In her concluding comments, she asserts that the continued interest in the 'Ripper'-in popular histories, fiction, films, and tourism-endorses the forms of violence to which the five murdered women were subjected. The book's explication of the historical contexts of the places and times of the five women's lives infers that they were vulnerable not only to their killer, but on so many fronts in late-Victorian society because they were women.

The Five is an absorbingly written, imaginative social history. It is a history of five women, the people with whom they tried to make their lives and with whom they were acquainted, and the places in which they sought out and found themselves. East London, both a site of deep poverty in Victorian Britain and one of the 'fictions' of the murders that Judith Walkowitz discusses, is a central landscape of these women's lives, as well as the place of their deaths. However, their stories move in and out of late-nineteenth-century Whitechapel across London, through the Kent countryside, the industrialized midlands, Paris and Gothenberg. The book traces the women's family backgrounds (encompassing those of agricultural workers, military families and skilled labourers); their schooling; employment; and experiences of illness, disease, and family and infant deaths. For each, alcohol was a source of comfort, which could become an addiction. In adulthood, they moved in and out of loving and abusive relationships with men, and between safety and rejection by family and friends, finding themselves as lone women, sometimes labelled as public nuisances (as drunkards or the carriers of sexually-transmitted diseases). Of the five women murdered, only Mary Jane Kelly was not homeless nor tramping the streets of Whitechapel on the night of her death; only Mary Jane was formally described as a 'Prostitute' (on her death certificate). Other sources of evidence, Rubenhold argues, show the women seeking out employment where they could: doing laundry, crocheting, making antimacassars, selling matches and flowers, hop-picking, in domestic service and factories, and hawking. Working in the sex trade was not the defining identity of these five women, not even of Mary Jane, even if more than one of them found themselves in need of selling their bodies for sex during their lifetimes.

Rubenhold states her ambition in this book is to discover the 'truth' of the five women's lives and deaths. She is, in fact, attentive precisely to the multiple perspectives of family, friends, partners, ex-lovers and the press that have framed the existing narratives of their lives, whilst she uses family history records to illuminate previously hidden parts of the women's life stories over a longer trajectory. The work of historical reconstruction that Rubenhold has undertaken is important both in the writing of the history of the Whitechapel murders and in the book's animus as a feminist project. Rubenhold's central concern is with the inequalities with which the five women struggled as a consequence of their class, age and in relation to the structures of the law, family and marriage. In all cases these 
inequalities were freighted by the inequalities they faced because of their gender. Finding ways to re-tell their stories, and to hear their voices, can be one part of the legacies of these women's lives.

Eve Colpus

University of Southampton

‥C.Colpus@soton.ac.uk 